\title{
AUDIT STRATEGI SUPPLY CHAIN MANAGEMENT DAN PRIORITAS SISTEM DISTRIBUSI (Studi Kasus pada Produsen Minuman Ringan)
}

\author{
Ridha Fithri Fathonah \\ Program Studi S2 Magister Manajemen Wijawiyata Manajemen \\ Sekolah Tinggi Manajemen PPM \\ Andi Ilham Said \\ Sekolah Tinggi Manajemen PPM
}

\begin{abstract}
Distribusi memegang peranan penting dalam kehidupan masyarakat sehari-hari. Distribusi merupakan proses penyampaian suatu produk dari tangan produsen ke konsumen. Tanpa distribusi, produsen akan mengalami kesulitan memasarkan produknya dan konsumen pun kesulitan untuk dapat menikmati produknya. Persaingan yang ketat membuat pengendalian proses distribusi produk menjadi salah satu aspek penentu dalam memenangkan persaingan. Saluran distribusi telah memasuki babak baru dalam arena persaingan bisnis. Ia bukan hanya digunakan untuk menjamin ketersediaan produk, tapi juga untuk kepentingan lainnya seperti sebagai media pembangun merek. Semakin strategisnya peran saluran membuat banyak perusahaan semakin serius menangani saluran distribusinya. Perusahaan - perusahaan bahkan berupaya agar saluran distribusinya menjadi kunci keunggulan bersaing.Salah satu produsen minuman ringan di Indonesia menyediakan produk-produknya dimanapun agar mudah dijangkau. Artinya produsen minuman ringan ini harus mendistribusikan produknya secara merata hingga ke tingkat pengecer paling bawah. Hal ini menuntut tingkat pengelolaan yang strategis pada sistem distribusinya. Untuk itu perlu dilakukan perancangan jaringan distribusi.Tujuan utama dari perancangan jaringan distribusi adalah untuk mengetahui prioritas wilayah distribusi dan prioritas outlet yang harus dilakukan agar perusahaan dapat menggali potensi suatu wilayah secara maksimal. Proses merancang jaringan distribusi terdiri dari Audit SCM, Audit Prioritas Wilayah Distribusi, dan Audit Prioritas Outlet Distribusi. Hasil audit ini berupa rumusan strategi rancangan jaringan distribusi dan rencana implementasinya.
\end{abstract}

Keywords:

Distribusi, supply chain management (SCM) 


\section{PENDAHULUAN}

Dalam era globalisasi ini, sudah banyak perusahaan yang mempertimbangkan efektifitas dan efisiensi waktu dalam proses pendistribusiannya. Banyak perusahaan tidak mampu memaksimalkan penjualannya hanya karena proses distribusi yang tidak efektif dan efisien.

Perubahan jalur distribusi akibat tuntutan konsumen untuk memperoleh produk dengan mudah membuat persaingan produk minuman siap saji di Indonesia cukup ketat. Data Nielsen Nurkory, produk manager PT ABC President Indonesia, mengatakan bahwa dari 200 juta botol minuman yang terjual setiap tahun, sebagian besar (70\%) merupakan air minum dalam kemasan (AMDK). Softdrink alias minuman berkarbonasi sekitar 8\%, minuman kesehatan (energy drink) 2\%, jus 2\%, dan teh $18 \%$ (Kodrat, 2009).

Industri minuman ringan Indonesia saat ini menyerap sekitar 50.000 orang yang dipekerjakan secara langsung, dan secara tidak langsung melibatkan sekitar 100.000 orang pekerja di sektor-sektor penunjang dan pemasok (supplier). Di tingkat distribusi. industri minuman ringan secara langsung membina dan memengaruhi penciptaan lapangan pekerjaan lebih dari 1 juta pedagang besar, menengah, dan kecil dengan jaringan pemasar hingga lebih dari 5 juta orang.

Persaingan industri minuman selain menggunakan iklan-iklan yang kreatif juga dibarengi oleh strategi pemasaran yang kuat terutama pada sisi saluran distribusi (delivery channel) dan distribusi fisik (physical distribution).

Agar produk-produk minuman ringan ini mudah dijangkau konsumennya maka produk-produk tersebut harus tersedia dimanapun. Hal ini menuntut tingkat pengelolaan yang strategis pada sistem distribusinya.

Untuk itu dilakukanlah analisis terhadap rancangan jaringan distribusi PT X sebagai salah satu produsen minuman di Indonesia guna mengetahui desain wilayah dan jaringan distribusi yang mendekatkan produk-produknya kepada konsumen.

Deliverables dari penulisan thesis ini adalah tersusunnya rancangan jaringan distribusi PT X guna mengetahui prioritas wilayah dan prioritas outlet distribusi dimasa yang akan datang.

\section{TINJAUAN PUSTAKA}

Rancangan jaringan distribusi yang efektif diperlukan untuk menentukan prioritas wilayah dan outlet yang akan difokuskan agar strategi distribusi dapat dijalankan secara maksimal dalam mencapai visi dan misi perusahaan.

Merujuk pada Gambar 1. proses evaluasi jaringan distribusi dilakukan melalui tiga tahap.

\subsection{Audit SCM}

\subsubsection{Audit Strategi Supply Chain}

Audit strategi supply chain dilakukan terhadap 5 komponen pembentuknya (Shoshanah Cohen \& Joseph Roussel, 2004).

a. Strategi Operasional Supply Chain

Strategi operasional supply chain yaitu strategi tentang bagaimana perusahaan akan memproduksi produknya. Strategi operasional supply chain ini akan menentukan bentuk dan optimalisasi supply chainnya, operasional pabrik, gudang, serta pemenuhan fasilitas yang dibutuhkannya. 


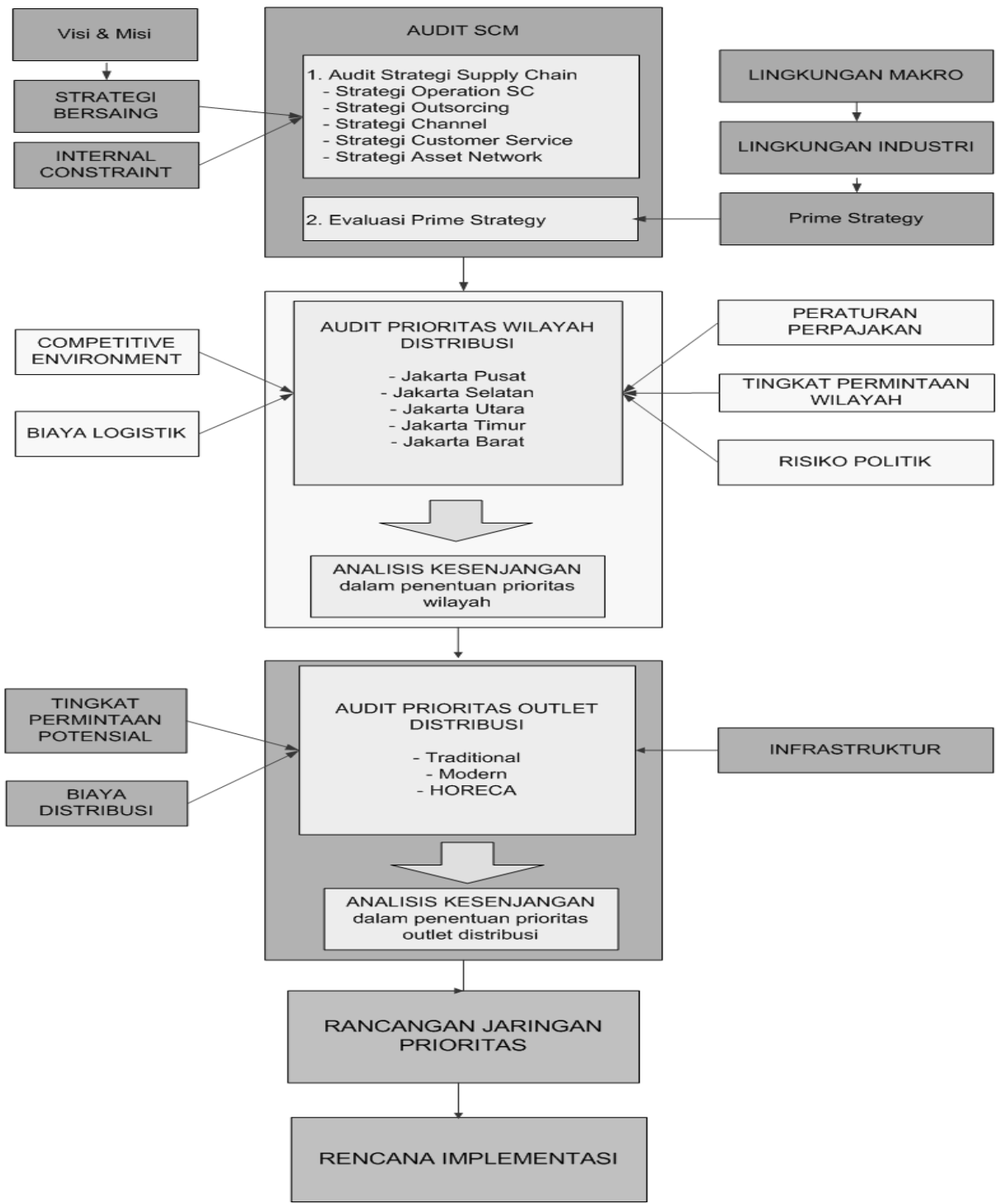

Gambar 1.

Kerangka Analisis Jaringan Distribusi 
b. Strategi Channel

Strategi channel menjelaskan bagaimana produk sampai ke konsumen. Strategi yang digunakan bisa berupa strategi distribusi secara langsung atau tidak langsung.

c. Strategi Customer Service

Strategi customer service adalah strategi yang dilakukan untuk memuaskan pelanggan. Caranya adalah dengan menyediakan produk sesuai pesanan dalam jangka waktu yang tepat.

d. Strategi Asset Network

Strategi asset network merupakan strategi yang digunakan untuk mengendalikan outlet asset dari pemasok hingga ke konsumen. Strategi asset network ini ditetapkan sesuai dengan tujuan perusahaan, apakah untuk mendapatkan biaya produksi yang rendah sehingga bisa menghasilkan harga jual produk yang kompetitif, ataukah untuk fleksibilitas proses produksi.

\subsubsection{Analisis Faktor Eksternal}

Dalam melakukan audit supply SCM perlu dilakukan analisis terhadap faktor eksternal dan internal yang mempengaruhinya. Analisis faktor eksternal terdiri atas analisis lingkungan makro dan analisis lingkungan industri. Dari analisis keduanya akan dihasilkan rumusan prime strategy perusahaan guna menghadapi peluang dan ancaman.

a. Analisis Lingkungan Makro

Dalam analisis lingkungan makro, menurut Lingga Purnama (2001), ada enam kekuatan utama lingkungan yang harus dipantau perusahaan yaitu demografi, ekonomi, lingkungan alam, teknologi, politik, dan sosial. b. Analisis Lingkungan Industri

Dalam analisis lingkungan industri, Lingga Purnama (2001) menjelaskan bahwa kekuatan yang membentuk lingkungan industri ada tiga yaitu pasar, pelanggan dan pesaing. Kekuatan pasar sangat dipengaruhi oleh pertumbuhan dan jenis saluran distribusinya. Sedangkan kekuatan pelanggan sangat dipengaruhi oleh daya beli, prilaku konsumen dan gaya hidup. Adapun kekuatan pesaing sangat dipengaruhi oleh bentuk persaingan, perusahaanperusahaan pesaing, dan market share.

Ada 4 strategi yang digunakan untuk merumuskan prime strategy perusahaan (Cohen dan Roussel, 2004) yaitu inovasi, biaya, kualitas dan pelayanan.

- $\quad$ Strategi Inovasi

Strategi inovasi dilakukan untuk mengembangkan variasi produk, kualitas produk, dan meningkatkan kualitas pelayanan. Pemanfaatan teknologi ditujukan untuk efisiensi biaya produksi agar mampu menghasilkan produk dengan harga yang murah.

- Strategi Biaya

Strategi biaya ditujukan untuk memenangkan persaingan harga. Hal ini dilakukan dengan cara efisiensi biaya. Efsiensi biaya distribusi dilakukan dengan mempersingkat jalur distribusi

- Strategi Kualitas

Strategi kualitas ditujukan untuk mengantisipasi permintaan konsumen akan produk yang berkualitas dalam hal keamanan bagi kesehatan dan lingkungan. Strategi kualitas juga menekankan pada kemampuan untuk mengendalikan mutu agar produk dapat sampai ke konsumen secara aman

- Strategi Pelayanan

Strategi pelayanan ditujukan untuk meningkatkan service level perusahaan kepada konsumennya melalui kecepatan 
dan ketepatan pengiriman pesanan ke konsumen. Hal ini dapat dicapai dengan sistem perencanaan pengiriman yang akurat, dan kerja sama dengan pihak ketiga dalam hal pengiriman dan pendistribusian produk.

\subsubsection{Analisis Faktor Internal}

Dalam audit SCM juga dilakukan analisis faktor internal dengan menganalisis strategi bersaing dan internal constraint.

a. Strategi Bersaing

Strategi bersaing dirumuskan dari visi \& misi perusahaan yang digunakan sebagai strategi bersaing perusahaan. Strategi bersaing melalui saluran distribusi merupakan strategi dalam bagaimana cara menjual produk, yang disesuaikan dengan keadaan para pesaing dalam lingkungan industri.

b. Internal Constraint

Internal constraints merupakan identifikasi keterbatasan yang dimiliki perusahaan yang berpotensi menghalangi tercapainya visi dan misi tersebut.

\subsubsection{Evaluasi prime strategy}

Evaluasi prime strategy ini dilakukan untuk mengetahui tingkat kesesuaian strategi dalam mengantisipasi peluang dan ancaman yang berasal dari faktor eksternal dan internal. Evaluasi ini dilakukan dengan sistem pembobotan menggunakan skala Likert. Dari hasil ini akan diketahui rangking tingkat kesesuaian komponen supply chain dari tingkat yang paling tinggi hingga yang terendah.

Menurut Cohen dan Roussel (2004), untuk menghasilkan strategi supply chain yang efektif maka kelima komponen strategi supply chain tersebut haruslah memenuhi empat kriteria sebagai berikut :

- Kesesuaian dengan strategi bisnis

- Kesesuaian dengan kebutuhan konsumen
- Kesesuaian dengan posisi perusahaan (power position)

- Adaptif sesuai dengan perubahan lingkungan dan perkembangan pasar.

Selanjutnya hasil evaluasi ini digunakan sebagai dasar untuk mengintegrasikan strategi supply chain dengan prime strategy. Integrasi ini dilakukan untuk mendapatkan basis kompetisi dalam pelaksanaan distribusi. Cohen dan Roussel (2004) menjelaskan bahwa basis kompetisi dapat dicapai melalui :

- Customer Collaborative Planning Merupakan penyusunan rencana distribusi yang didasarkan pada kebutuhan konsumen.

- Customer Segmentation

Merupakan pembagian konsumen berdasarkan tingkat kebutuhannya, jenis salurannya, sistem pemesanan, sistem pembayaran dsb.

- Postponement

Menurut Sunil Chopra dan Peter Meindl (2007), postponement adalah kemampuan supply chain dalam menunda proses finalisasi sebelum produk tersebut terjual. Selain lebih menguntungkan bagi konsumen, praktek ini juga bisa mempersingkat proses produksi. Sehingga konsumen bisa mendapatkan produk sesuai yang diinginkannya dalam waktu cepat.

\subsection{Audit Prioritas Wilayah Distribusi}

Audit prioritas wilayah distribusi ditujukan untuk menentukan prioritas wilayah distribusi dengan berbagai kriteria yang berbeda. Kriteria wilayah dibedakan menjadi wilayah pusat, timur, selatan, barat dan utara. Dalam audit prioritas wilayah dilakukan analisis faktor eksternal dan internal yang mempengaruhinya. 


\subsubsection{Analisis Faktor Eksternal}

a. Peraturan Perpajakan

Peraturan perpajakkan sangat berpengaruh terhadap beban biaya yang harus dikeluarkan akibat aktivitas distribusi di suatu wilayah.

b. Tingkat Permintaan Wilayah Besarnya tingkat permintaan ditunjukkan oleh tingkat pertumbuhan penjualan perusahaan di wilayah tersebut.

c. Risiko Politik

Risiko politik merupakan suatu risiko yang muncul akibat perubahan politik di suatu wilayah atau negara.

\subsubsection{Analisis Faktor Internal}

a. Competitive Environment

Dalam analisis competitive environment akan diidentifikasi kelayakan suatu wilayah sebagai prioritas distribusi, dengan melihat tingkat persaingan yang terjadi di wilayah tersebut.

b. Biaya Logistik

Biaya logistik berhubungan langsung dengan kebijakan pelayanan, yaitu tingkat ketersediaan yang tinggi, tingkat pelayanan yang cepat dan konsisten, serta kualitas yang tinggi.

\subsubsection{Evaluasi Prioritas Wilayah Distribusi}

Proses evaluasi dilakukan dengan metode AHP (Analytic Hierarchy Process) untuk mendapatkan rangking potensi wilayah. Penentuan prioritas wilayah distribusi ditetapkan berdasarkan urutan (ranking) tersebut.

\subsubsection{Analisis Prioritas Wilayah Distribusi \\ Dalam menganalisis prioritas} wilayah digunakan analisis kesenjangan, untuk menginventarisasi fokus perusahaan dan kebutuhan dimasa yang akan datang.

\subsection{Audit Prioritas Outlet Distribusi}

Audit prioritas outlet distribusi ini untuk menentukan tipe outlet distribusi yang potensial sebagai prioritas distribusi. Tipe outlet berupa outlet tradisional, outlet modern, dan HORECA (Hotel, Restaurant, Cafe/Canteen).

\subsubsection{Analisis Faktor Eksternal}

Analisis faktor eksternal dilakukan terhadap kondisi infrastruktur di wilayah yang diprioritaskan. Menurut Kotler (2009), kondisi infrastruktur ini harus memenuhi kriteria ekonomis, kontrol dan adaptif. Kriteria ekonomis diimplementasikan dalam bentuk kemampuan outlet tersebut dilihat dari segi biaya. Sedangkan kriteria kontrol diimplementasikan berupa kemampuan outlet dalam menyebarkan dan menyerap produk. Sedangkan kriteria adaptif diimplementasikan dari kemampuan outlet tersebut dalam mengantisipasi perubahan prilaku konsumen.

\subsubsection{Analisis Faktor Internal}

Analisis faktor internal merupakan penjabaran dari kriteria ekonomis (Kotler, 2009).

a. Biaya Distribusi

Biaya distribusi adalah biaya yang harus ditanggung dalam mendistribusikan produk ke berbagai jenis outlet. Biaya ini meliputi biaya pengiriman yaitu biaya operasional armada pengiriman, biaya tenaga kerja dan biaya lainnya terkait kerjasama dengan pihak outlet.

b. Tingkat Permintaan Wilayah

Tingkat permintaan wilayah diukur dari besarnya tingkat permintaan yang ada di suatu outlet dan kemampuan finansial dari outlet tersebut. 


\subsubsection{Faktor - faktor dalam penentuan prioritas outlet distribusi}

Faktor-faktor yang menjadi pertimbangan dalam penentuan prioritas outlet distribusi perlu diukur pengaruhnya (kepentingannya) sebagai dasar pengolahan AHP. Pengukuran ini dilakukan dengan menggunakan skala Likert. Dari sini akan diketahui faktor yang paling berpengaruh dalam penentuan prioritas outlet distribusi.

\subsubsection{Evaluasi Outlet Distribusi}

Evaluasi ini ditujukan untuk mengetahui potensi outlet. Dengan menggunakan metode AHP akan didapatkan urutan prioritas (rangking) dari tipe-tipe outlet yang berpotensi dalam menghasilkan volume penjualan tertinggi dengan biaya yang minimal.

\subsubsection{Analisis Outlet Distribusi}

Analisis terhadap outlet distribusi dilakukan untuk mengetahui kemungkinan suatu tipe outlet ditetapkan sebagai prioritas distribusi dimasa yang akan datang. Disini akan digunakan analisis kesenjangan untuk menginventarisasi fokus perusahaan dan kebutuhan dimasa yang akan datang.

\subsubsection{Rancangan Jaringan Distribusi} Rancangan jaringan distribusi merupakan langkah strategis dalam mengimplementasikan hasil perumusan prime strategy, penetapan prioritas wilayah dan penetapan prioritas outlet distribusi. Rancangan ini disusun berdasarkan analisis terhadap kinerja jaringan distribusi selama ini di wilayah distribusi yang ditetapkan sebagai prioritas. Di dalam rancangan ini akan dijabarkan pula rencana implementasi dan manajemen risiko untuk menghadapi permasalahan-permasalahan potensial.

\section{METODOLOGI}

Untuk menentukan prioritas wilayah dan outlet distribusi digunakan metode AHP. Metode AHP diawali dengan menetapkan tujuan guna menentukan prioritas wilayah dan outlet distribusi dari berbagai alternatif yang ada. Dalam menentukan prioritas ini dirumuskan kriteria yang selanjutnya diturunkan lagi menjadi sub kriteria. Kemudian dilakukan penggabungan (synthesis) terhadap seluruh kriteria dan sub kriteria yang ada untuk menentukan alternatif mana yang dipilih. Keputusan pemilihan alternatif ini didasarkan pada nilai tertinggi hasil penggabungan.

Pengolahan AHP ini menggunakan perangkat lunak Expert Choice. Expert Choice adalah sebuah sistem yang digunakan untuk menganalisis, menggabungkan dan memutuskan suatu pilihan yang kompleks serta mengevaluasinya. (Expert Choice Inc, 1995).

\section{PEMBAHASAN}

\subsection{Audit SCM}

\subsubsection{Analisis Faktor Eksternal}

Analisis eksternal terdiri dari analisis terhadap lingkungan makro dan lingkungan industri. Perubahan yang terjadi pada faktor eksternal akan mempengaruhi tingkat permintaan konsumen, mempengaruhi jenisjenis produk yang akan dikembangkan, strategi segmentasi pasar dan positioning, serta bentuk pelayanan ditawarkan.

a. Analisis Lingkungan Makro

Analisis lingkungan makro penting dilakukan perusahaan untuk menentukan prime strategy dalam mencapai visi dan misi perusahaan. Berdasarkan analisis lingkungan yang telah dilakukan dapat disimpulkan bahwa produsen minuman ringan ini menerapkan strategi pelayanan sebagai strategi utamanya. Strategi 
pelayanan ini dipilih karena merupakan strategi yang paling sering digunakan dan cukup potensial untuk mengantisipasi peluang dan ancaman pada aspek demografi, ekonomi dan teknologi.

- Pada aspek demografi, strategi pelayanan digunakan untuk menghadapi berbagai tipe konsumen yang berasal dari berbagai lapisan masyarakat dengan berbagai usia. Dalam hal ini, strategi pelayanan dilakukan dengan menyediakan produk dimana saja yang mendekatkannya kepada konsumen dalam waktu yang cepat. Strategi pelayanan mampu menyebarkan produk dengan cepat hingga level terendah. Sehingga memudahkan perusahaan menangkap peluang pasar di berbagai segmen yang dilayaninya.

- Pada aspek ekonomi, strategi pelayanan digunakan untuk menghadapi maraknya pemberdayaan UMKM dan koperasi sebagai jaringan distribusi. Strategi pelayanan dilakukan untuk memperluas jangkauan dengan memanfaatkan UMKM dan koperasi sebagai pihak yang menyebarkan produk. Dengan demikian strategi pelayanan sangat potensial untuk menghadirkan produk dimanapun dalam waktu cepat. Selain itu strategi pelayanan digunakan untuk menghadapi pesatnya perkembangan pasar modern yang menerapkan lowest price strategy.

- Dalam aspek teknologi, strategi pelayanan digunakan untuk menghadapi kecepatan pemrosesan order dari pabrik ke konsumen. Teknologi dibutuhkan untuk mendukung terciptanya service level yang tinggi. Strategi pelayanan dilakukan dengan memaksimalkan sumber daya agar proses pengiriman order bisa dilaksanakan dengan cepat dan tepat. b. Analisis Lingkungan Industri

Analisis lingkungan industri ini akan mengidentifikasikan peluang dan ancaman di dalam industri yang digelutinya. Analisis ini dilakukan terhadap pasar, pelanggan, dan pesaing. Berdasarkan analisis lingkungan industri yang telah dilakukan dapat disimpulkan bahwa produsen minuman ringan lebih menerapkan strategi pelayanan sebagai strategi utamanya. Strategi pelayanan ini dipilih karena merupakan strategi yang paling sering digunakan untuk mengantisipasi berbagai aspek pasar, pelanggan, dan pesaing. Ketiga aspek tersebut memberikan peluang bagi perusahaan untuk mendistribusikan produknya seluas mungkin di setiap level. Namun dibalik peluang tersebut ada persaingan tinggi yang mengancam. Pelayanan menjadi strategi diferensiasi untuk menghadapi persaingan.

- Pada aspek pasar, strategi pelayanan digunakan untuk menghadapi pertumbuhan pasar dan perkembangan saluran distribusi. Pertumbuhan pasar yang kondusif harus diantisipasi dengan kelancaran distribusi produk agar penjualan dapat tumbuh seiring dengan tumbuhnya pasar. Kelancaran distribusi harus didukung oleh strategi pelayanan agar dapat melayani semua segmen konsumen agar perluasan jangkauan (coverage) dapat dicapai. Strategi pelayanan diwujudkan melalui penyediaan berbagai variasi produk agar bisa melayani semua segmen konsumen.

- Pada aspek pelanggan, strategi pelayanan dilakukan untuk menghadapi beragamnya daya beli konsumen. Pengelolaan distribusi di setiap segmen dapat dilakukan dengan strategi pelayanan yang mendistribusikan produk secara merata. Strategi pelayanan juga digunakan untuk mengantisipasi 
perkembangan prilaku konsumen dan perubahan gaya hidup. Dengan menggunakan berbagai saluran distribusi maka potensi penjualan dapat ditingkatkan.

- Pada aspek pesaing, strategi pelayanan dilakukan untuk menghadapi berkembangnya industri minuman yang beranekaragam jenis dan variasinya. Strategi pelayanan dilakukan melalui kecepatan pemrosesan pesanan agar produk hadir lebih cepat dari pesaing, dan menjamin ketersediaan produk agar konsumen bisa mendapatkan produk dengan mudah. Strategi pelayanan juga dilakukan untuk meningkatkan market share dengan pendistribusian produk yang dilakukan bekerjasama dengan pihak ketiga agar jangkauan lebih luas dan biaya efisien.

Analisis data dilakukan dengan pendekatan Two-Step Approach menggunakan Program SIMPLIS (Simple Lisrel), yaitu:

- Membuat program SIMPLIS untuk model pengukuran (model CFA) di mana hubungan yang dimasukkan pada program adalah hubungan masing-masing variabel teramati (indikator) dengan variabel latennya.

- Membuat program SIMPLIS untuk model hybrid (Full SEM), di mana model struktural (hubungan di antara variabel laten) ditambahkan pada model pengukuran (model CFA).

\subsubsection{Analisis Faktor Internal}

Analisis ini meliputi analisis terhadap strategi bersaing (competitive strategy) dan internal constraints (Chopra dan Meindl, 2007).

a. Competitive Strategy

Strategi bersaing adalah strategi perusahaan dalam memenuhi kebutuhan konsumen melalui produk yang dihasilkannya. Dari analisis lingkungan makro dan industri diketahui bahwa strategi pelayanan adalah strategi yang paling sering digunakan untuk mengantisipasi peluang dan ancaman yang ada. Oleh karena itu, strategi pelayanan merupakan strategi utama PT $\mathrm{X}$.

b. Internal Constraints

Internal constraints merupakan keterbatasan yang dimiliki perusahaan dalam memenuhi permintaan konsumen, menempatkan supply point, mengatur pengiriman dan mengoptimalkan armada pengiriman, memaksimalkan sumber daya yang dimiliki, serta memproses pesanan. Analisis internal constraint ini berguna untuk menentukan fasilitas apa saja yang masih dibutuhkan untuk merancang outlet distribusi. Dari hasil pengamatan diketahui ada beberapa Internal Constraints yang dihadapi PT. $\mathrm{X}$, yaitu :

- Keterbatasan jumlah armada pengiriman.

- Keterbatasan teknologi informasi untuk kelancaran komunikasi antara outlet, gudang dan pabrik.

- Keterbatasan jumlah SDM yang menguasai teknologi pendukung.

- Keterbatasan jumlah fasilitas untuk outlet.

\subsubsection{Audit Strategi Supply Chain}

a. Strategi Operasional Supply Chain

Dalam evaluasi kesesuaian untuk mencapai strategi supply chain yang efektif, hasil pembobotan komponen strategi operasional supply chain menunjukkan nilai 4,45. Artinya komponen ini telah memenuhi kriteria kesesuaian karena total nilai pembobotannya lebih dari 4.

b. Strategi Outsourcing

Berdasarkan hasil pembobotan, komponen outsourcing ini menghasilkan 
total nilai kesesuaian sebesar 4,00. Nilai pembobotan ini masuk ke dalam kategori sesuai. Artinya, dalam strategi supply chainnya PT X lebih mengoptimalkan kemampuan sendiri.

c. Strategi Channel

Hasil pembobotan menunjukkan nilai total sebesar 4,05. Artinya strategi channel ini sudah sesuai dengan kriteria supply chain yang efektif.

d. Strategi Customer Service

Menurut hasil pembobotan, total nilai kesesuaian sebesar 4,20. Artinya customer service strategy sudah sesuai dengan kriteria supply chain yang efektif.

e. Strategi Asset Network

Hasil pembobotan menunjukkan total nilai sebesar 4,05. Artinya, strategi asset network telah sesuai dengan kriteria supply chain yang efektif.

\subsubsection{Evaluasi Prime Strategy}

Kesesuaian dengan strategi bisnis memiliki bobot 35\%. Dalam hal ini pelayanan sebagai prime strategy diterapkan untuk mencapai visi dan misi. Sedangkan kesesuaian dengan kebutuhan konsumen memiliki bobot yaitu 25\%. Dalam hal ini pelayanan menjadi dasar bagi perumusan strategi bisnis lainnya.

Adapun kesesuaian dengan kekuatan perusahaan memiliki bobot 25\%. Dalam hal ini PT $\mathrm{X}$ mengoptimalkan kapasitasnya untuk menjalankan pelayanan. Sedangkan adaptif memiliki bobot 15\%. Dalam hal ini strategi pelayanan diterapkan untuk menghadapi berbagai perubahan.

Selanjutnya hasil evaluasi prime strategy ini digunakan sebagai dasar untuk mengintegrasikan strategi supply chain dengan prime strategy. Integrasi ini dilakukan untuk mendapatkan basis kompetisi dalam pelaksanaan distribusi.
a. Customer Collaborative Planning

Komponen supply chain yang digunakan untuk menghadapi peluang dan ancaman adalah strategi outsorcing dan strategi channel. Strategi outsorcing dilakukan untuk menghadapi peluang dalam mendistribusikan produk secara luas dengan jumlah yang besar. Selain itu outsorcing juga digunakan untuk mengatasi keterbatasan (internal constraint) perusahaan. Sedangkan kekuatan strategi channel diterapkan untuk meningkatkan efektifitas penyebaran produk dan efisiensi biaya.

b. Customer Segmentation

Pada customer segmentation, strategi pelayanan dilakukan berdasarkan kebutuhan dari masing-masing segmen konsumen. Antisipasi terhadap peluang dan ancaman dilakukan dengan menggunakan kekuatan strategi customer service dan strategi asset network. Strategi customer service memiliki bobot sebesar 4,25 dan strategi asset network sebesar 4,00. Kedua hasil tersebut menunjukkan bahwa strategi yang telah diterapkan PT X sudah tepat.

c. Postponement

Postponement merupakan basis kompetisi perusahaan dalam memenuhi permintaan konsumen. Dalam postponement ini kekuatan supply chain yang digunakan adalah strategi operasional supply chain. terutama diterapkan guna mengantisipasi peluang dan ancaman pada pengiriman. Hasil pembobotan strategi operasional supply chain adalah 4,45. Artinya strategi yang diterapkan PT X sudah tepat. Ketepatan strategi operasional supply chain bisa dilihat dari perubahan sistem conventional route selling menjadi preselling route untuk meningkatkan kualitas pelayanan. 


\subsection{Audit Prioritas Wilayah Distribusi 4.2.1 Analisis Faktor Eksternal}

Analisis terhadap faktor eksternal dilakukan untuk menilai besarnya potensi suatu wilayah untuk dijadikan sebagai prioritas distribusi. Analisis faktor eksternal dilakukan terhadap peraturan perpajakan, besarnya kebutuhan ditingkat regional dan besarnya risiko politik yang ada di wilayah tersebut.

Analisis terhadap peraturan perpajakan menunjukkan bahwa belum ada peraturan khusus yang mengatur distribusi. Hal ini membuat peluang untuk mendistribusikan produk terbuka luas di semua wilayah. Sehingga setiap perusahaan bebas menyebarkan produknya kemana saja sesuai dengan kapasitas yang dimilikinya asalkan masih mengikuti ketentuan dasar yang berlaku. Untuk itu, distribusi diprioritaskan pada wilayah yang masyarakatnya memiliki penghasilan tinggi. Untuk menganalisis tingkat permintaan di suatu wilayah dapat dilihat dari banyaknya masyarakat yang berusia remaja hingga dewasa. Karena mereka sudah memiliki kebebasan memilih produk yang mereka sukai. Selain itu tingkat masyarakat yang berpenghasilan juga mempengaruhi permintaan. Karena masyarakat yang berpenghasilan inilah yang berpotensi melakukan pembelian. Tingkat pengangguran juga berpengaruh terhadap besarnya permintaan di suatu wilayah. Tingkat pengangguran merupakan indikator ekonomi. Jika tingkat pengangguran rendah berarti terjadi penyerapan tenaga kerja karena meningkatnya investasi. Dengan demikian perekonomian di wilayah tersebut membaik.

Sedangkan analisis terhadap besarnya risiko politik dapat dilihat dari besarnya tingkat pengangguran. Karena tingkat pengangguran yang tinggi memicu terjadinya gerakan unjuk rasa yang bisa mengarah ke tindakan anarkis.

\subsubsection{Analisis Faktor Internal}

Analisis faktor internal dilakukan terhadap competitive environment dan beban biaya logistik yang dikeluarkan. Analisis competitive environment ditujukan untuk mengkaji kelayakan suatu wilayah sebagai prioritas distribusi dilihat dari unsur demografi suatu wilayah. Demografi ini diantaranya adalah pertumbuhan penduduk, tingkat kepadatan penduduk, dan luas wilayah. Sedangkan analisis biaya dilakukan untuk mengetahui beban biaya logistik yang harus ditanggung untuk mendistribusikan produk di wilayah tersebut. Dalam hal ini, biaya logistik dipengaruhi oleh tingkat harga tanah di suatu wilayah.

\subsubsection{Audit Prioritas Wilayah Distribusi}

Dengan menggunakan metode AHP (Gambar 2.) didapatkan bahwa Jakarta Timur merupakan wilayah yang paling tinggi potensinya (Tabel 1.). Oleh karena itu Jakarta Timur menjadi prioritas pertama dalam pendistribusian. Hal ini dikarenakan Jakarta Timur memiliki tingkat pertumbuhan penduduk paling tinggi hingga lima tahun mendatang dan memiliki jumlah penduduk berusia 15+ terbanyak. Faktor kependudukan ini merupakan potensi besar untuk memasarkan suatu produk. Sedangkan dilihat dari luasnya, Jakarta Timur merupakan wilayah yang terluas di DKI Jakarta. Hal ini merupakan faktor potensial untuk memperluas jangkauan (coverage). Dilihat dari kisaran harga tanah, Jakarta Timur memiliki kisaran harga tanah yang relatif lebih murah dibanding wilayah lain di Jakarta. Faktor harga ini cukup penting untuk menentukan letak pusat distribusi. Karena harga akan menjadi beban biaya bagi pengoperasian suatu pusat distribusi. Besar 
kecilnya beban biaya ini akan berpengaruh pada harga jual.

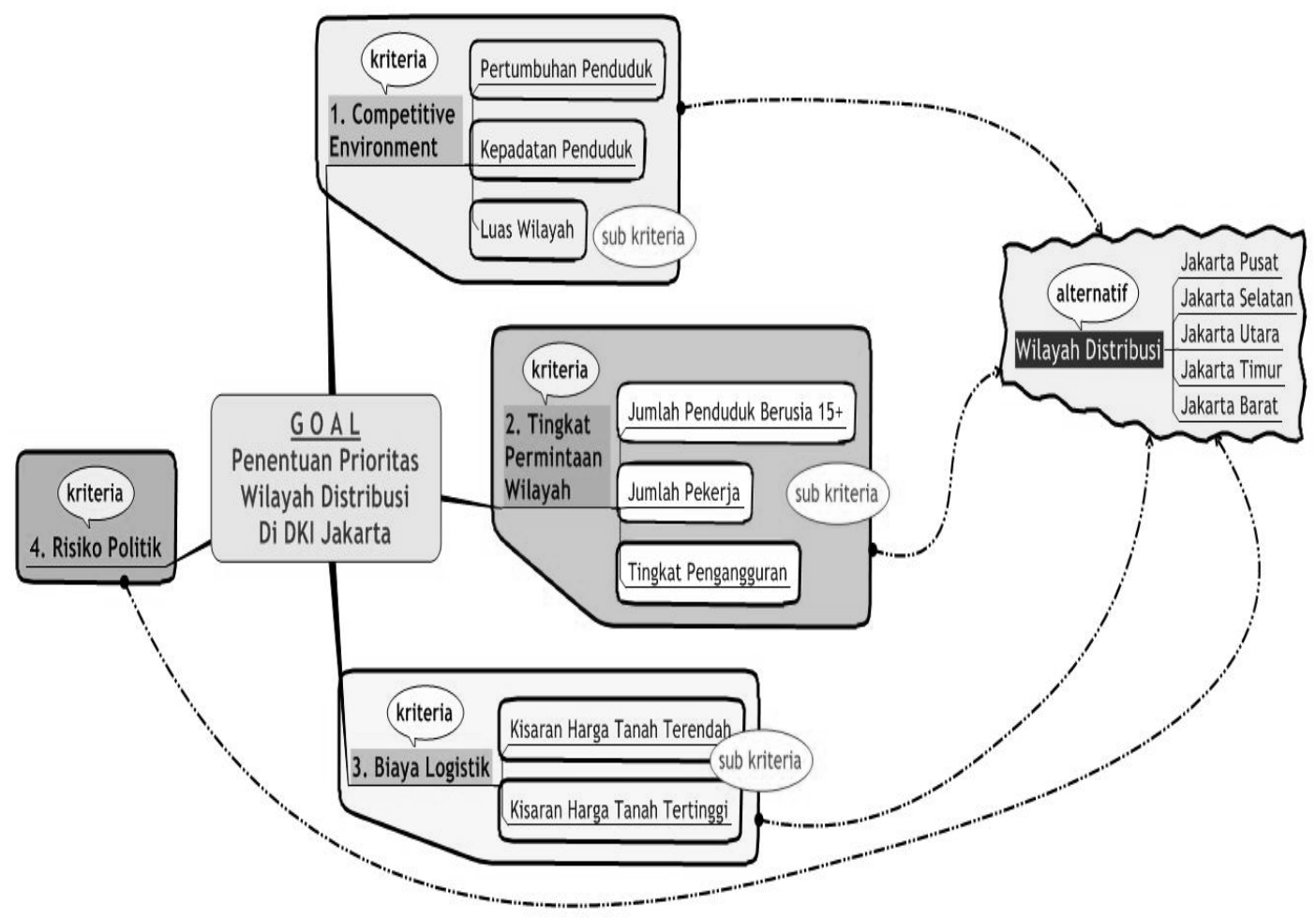

Gambar 2.

Kerangka AHP Dalam Penentuan Prioritas Wilayah Distribusi

Tabel 1.

Urutan Prioritas Wilayah Distribusi Hasil Pengolahan AHP

\begin{tabular}{|l|r|}
\multicolumn{2}{|c|}{$\begin{array}{c}\text { Urutan Prioritas Wilayah Distribusi } \\
\text { Hasil Pengolahan AHP }\end{array}$} \\
\hline \multicolumn{1}{|c|}{ Wilayah } & Hasil AHP \\
\hline Jakarta Timur & $28.10 \%$ \\
\hline Jakarta Barat & $25.20 \%$ \\
\hline Jakarta Utara & $20.60 \%$ \\
\hline Jakarta Selatan & $16.40 \%$ \\
\hline Jakarta Pusat & $9.60 \%$ \\
\hline Overall Inconsistency Index $=0.05$ \\
\hline
\end{tabular}




\subsubsection{Analisis Prioritas Wilayah Distribusi}

Hasil perumusan prime strategy produsen minuman ringan ini adalah pelayanan. Sedangkan dari evaluasi prioritas wilayah, diketahui bahwa PT X tidak menetapkan prioritas wilayah distribusi. Hingga saat ini PT $X$ memfokuskan distribusinya pada luas jangkauan wilayah (coverage area). Sedangkan untuk menghadapi persaingan dimasa depan diperlukan penetapan prioritas wilayah distribusi agar dapat diketahui kekuatan pangsa pasarnya di wilayah tersebut (Gambar 3.).

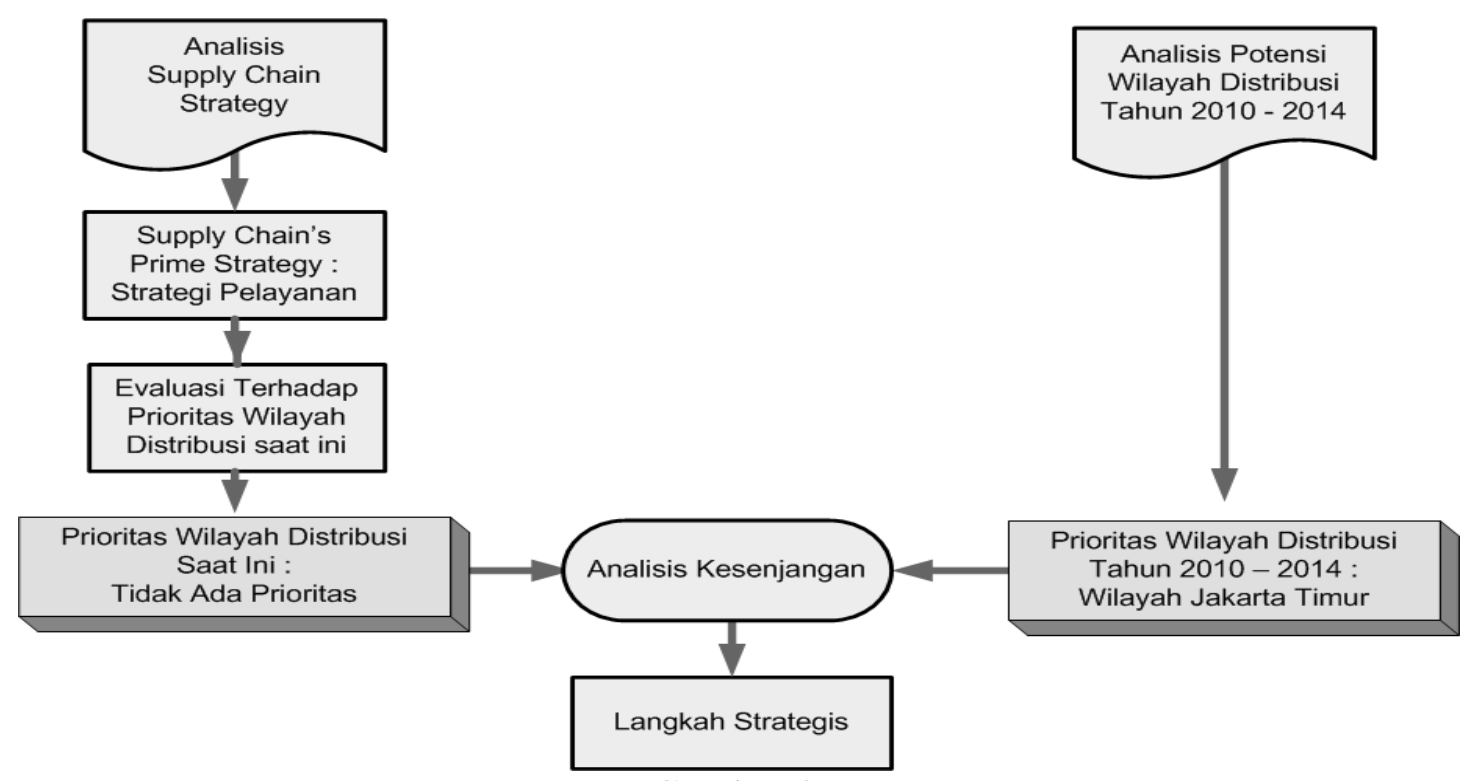

Gambar 3.

Analisis Kesenjangan dalam Penentuan Prioritas Wilayah Distribusi

\subsection{Audit Prioritas Outlet Distribusi}

Audit ini ditujukan untuk menentukan tipe outlet distribusi yang potensial sebagai prioritas distribusi. Audit prioritas outlet distribusi ini diawali dengan menganalisis faktor eksternal dan internal yang mempengaruhinya. Faktor-faktor ini selanjutnya digunakan sebagai dasar pengolahan metode AHP. Hasil AHP digunakan untuk mengevaluasi jaringan yang telah diterapkan.

\subsubsection{Analisis Faktor Eksternal}

Analisis faktor eksternal ditinjau dari infrastruktur yang ada di wilayah prioritas.
Ada tiga permasalahan yang terkait dengan outlet sebagai infrastruktur distribusi yaitu kemampuannya dalam menyebarkan produk hingga ke level terendah yang terdekat dengan konsumen, kemampuannya dalam menyerap produk baik dari jenis maupun jumlahnya serta kemampuannya dalam mengikuti perubahan prilaku konsumen.

\subsubsection{Analisis faktor Internal}

Analisis faktor internal merupakan penjabaran dari kriteria ekonomis (Kotler, 2009). Dalam kriteria ini, kriteria ekonomis dilihat dari sisi biaya distribusi dan tingkat permintaan wilayah. Besarnya biaya menjadi 
faktor pertimbangan penentuan prioritas outlet agar tujuan perusahaan untuk melayani pasar dengan biaya minimal dapat tercapai.

Sedangkan tingkat permintaan potensial diukur dari tingkat permintaan yang didasarkan data penjualan masingmasing outlet dan kemampuan finansial outlet tersebut. Semakin tinggi tingkat permintaan suatu outlet semakin tinggi pula kapasitasnya. Artinya outlet tersebut harus semakin diprioritaskan untuk segera dilayani. Dalam merencanakan outlet, perusahaan harus melihat kapasitas daya beli outlet tersebut.

Kapasitas daya beli ini dilihat dari kemampuan finansial suatu outlet agar perusahaan memiliki jaminan kepastian pembayaran dari outlet.

\subsubsection{Evaluasi Prioritas Outlet Distribusi}

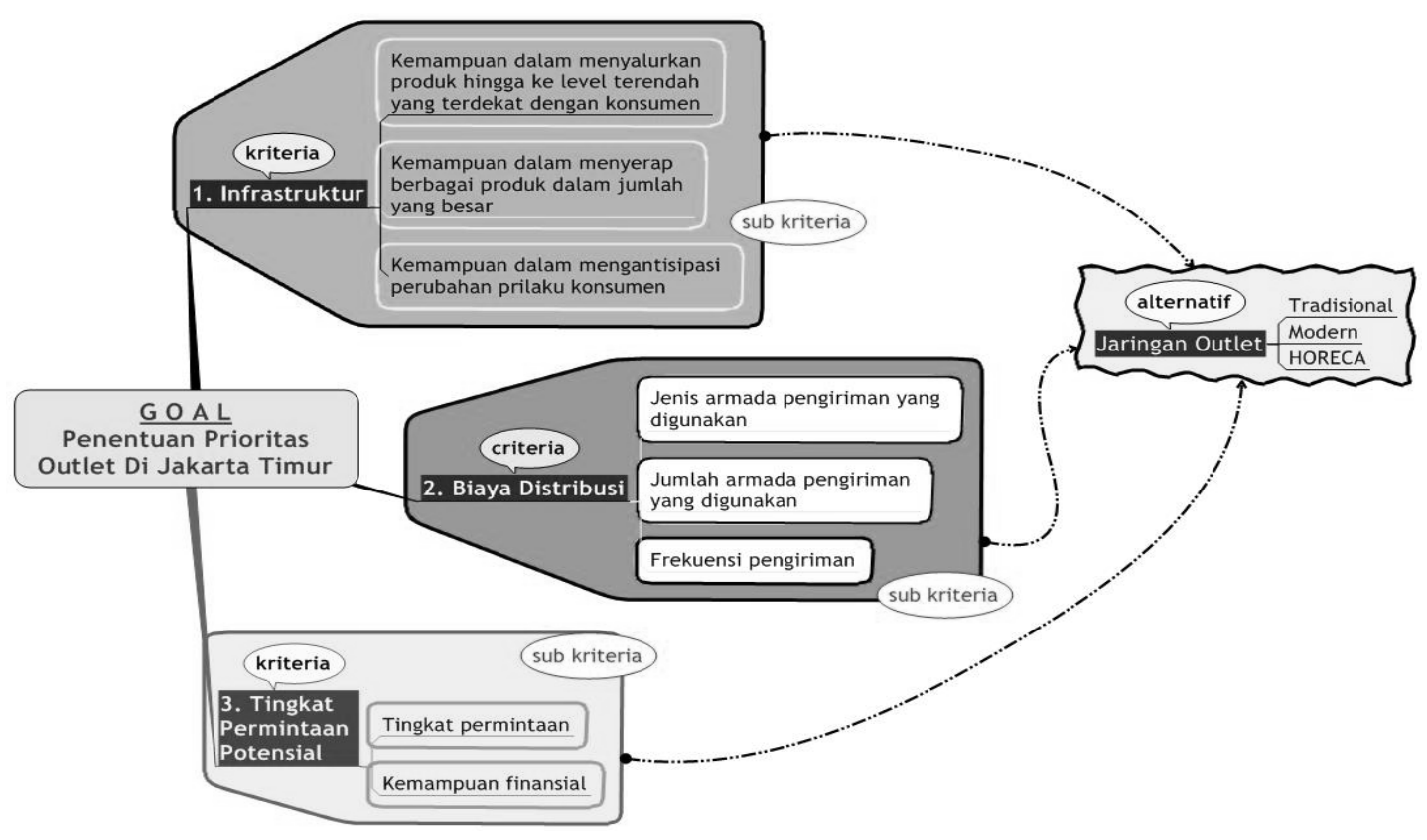

Gambar 4.

Kerangka AHP dalam Penentuan Prioritas Outlet Distribusi

Tabel 2.

Urutan Prioritas Outlet Distribusi

Urutan Prioritas Jaringan Distribusi Hasil Pengolahan AHP

\begin{tabular}{|l|c|}
\hline \multicolumn{1}{|c|}{ Jenis Outlet } & Prosentase \\
\hline TRADISIONAL & $37.10 \%$ \\
\hline MODERN & $36.00 \%$ \\
\hline HORECA & $27.00 \%$ \\
\hline
\end{tabular}

Overall Inconsistency Index $=0.05$ 
Hasil penggabungan (synthesis) AHP (Gambar 4.) didapatkan urutan prioritas outlet distribusi dimana outlet tradisional merupakan prioritas pertama (Tabel 2.). Meskipun dari sisi biaya, outlet tradisional memiliki biaya distribusi tertinggi, namun outlet ini sangat potensial untuk meningkatkan penjualan perusahaan. Tingginya biaya distribusi pada outlet ini masih relevan karena jumlahnya juga lebih banyak sehingga frekuensi pengiriman juga lebih sering.

\subsubsection{Analisis Prioritas Outlet Distribusi}

Dari evaluasi diketahui bahwa PT X memprioritaskan distribusinya pada outlet modern. Hal ini kurang sesuai dengan visi dan misi perusahaan yang memfokuskan distribusinya pada luas jangkauan wilayah (coverage area).

Hasil analisis prioritas outlet distribusi menunjukkan bahwa jaringan distribusi yang sesuai untuk menghadapi persaingan tahun 2010 - 2014 adalah outlet tradisional. Outlet tradisional ini akan menjadi ujung tombak distribusi karena sangat efektif untuk memperluas jangkauan (coverage) dan memperkuat market share. Selain itu outlet tradisional juga sebagai sarana untuk launching produk baru guna memancing permintaan (demand) di outletoutlet yang lebih besar.

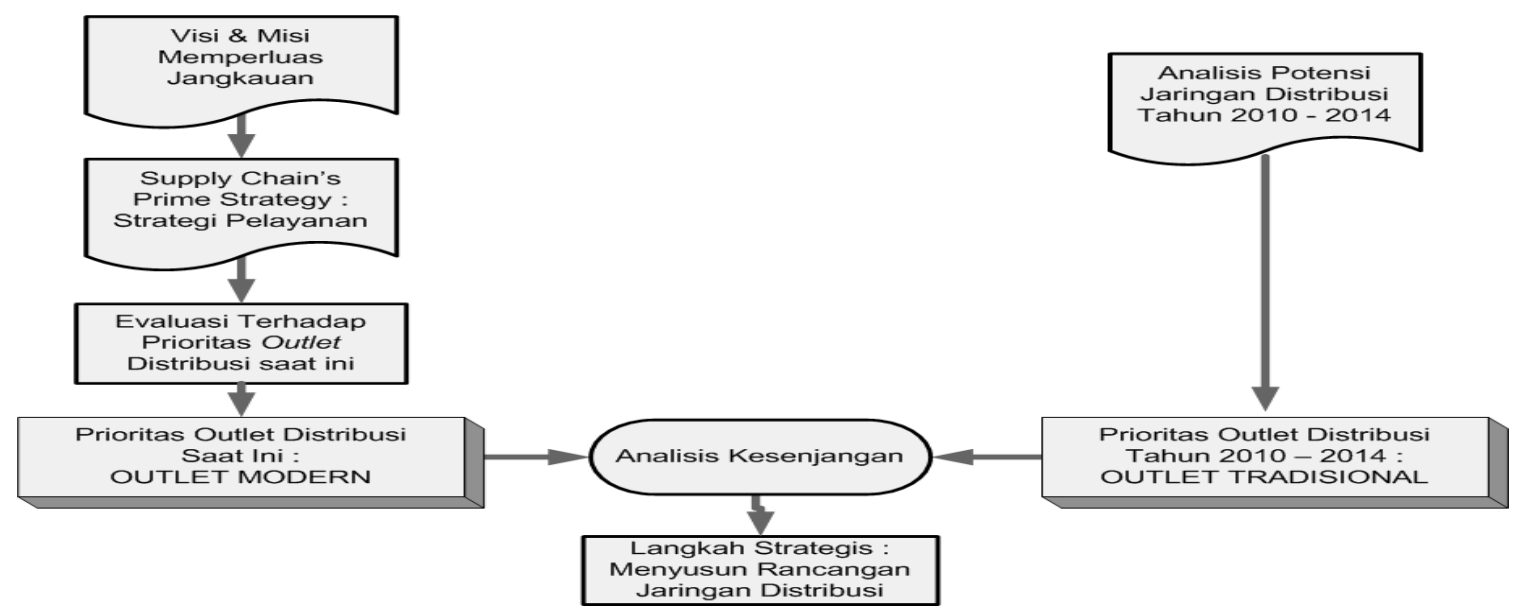

Gambar 5.

Analisis Kesenjangan dalam Penentuan Prioritas Outlet Distribusi Tahun 2010-2014

\subsection{Rancangan Jaringan Distribusi}

a. Menghapuskan sistem distribusi langsung untuk outlet tradisional dan menyerahkan fungsi penyebaran produk kepada pihak ketiga. Hal ini dilakukan untuk meningkatkan efisiensi biaya dengan service level tetap tinggi (Gambar 6.).

b. Mengembangkan sistem distribusi secara horizontal dengan cara menambah jumlah pihak ketiga agar jangkauan penyebaran semakin luas dan efektif, terutama di daerah yang kemacetannya tinggi namun merupakan titik penjualan potensial. Potensi untuk menambah TPP di wilayah Jakarta Timur masih sangat besar.

c. Mengembangkan sistem distribusi secara vertikal, artinya menambah variasi produk didalam setiap outlet. Dalam hal ini, PT $\mathrm{X}$ harus membidik produkproduk yang tingkat penjualannya tinggi. Misalkan di outlet yang berada di jalur kemacetan tinggi, maka produk yang 
sebaiknya dijual adalah minuman ringan yang tingkat kesegarannya tinggi.

d. Melakukan perubahan sistem penjualan dari conventional selling menjadi pre- selling untuk meningkatkan akurasi perencanaan distribusi agar efisiensi dapat ditingkatkan (Gambar 6.).

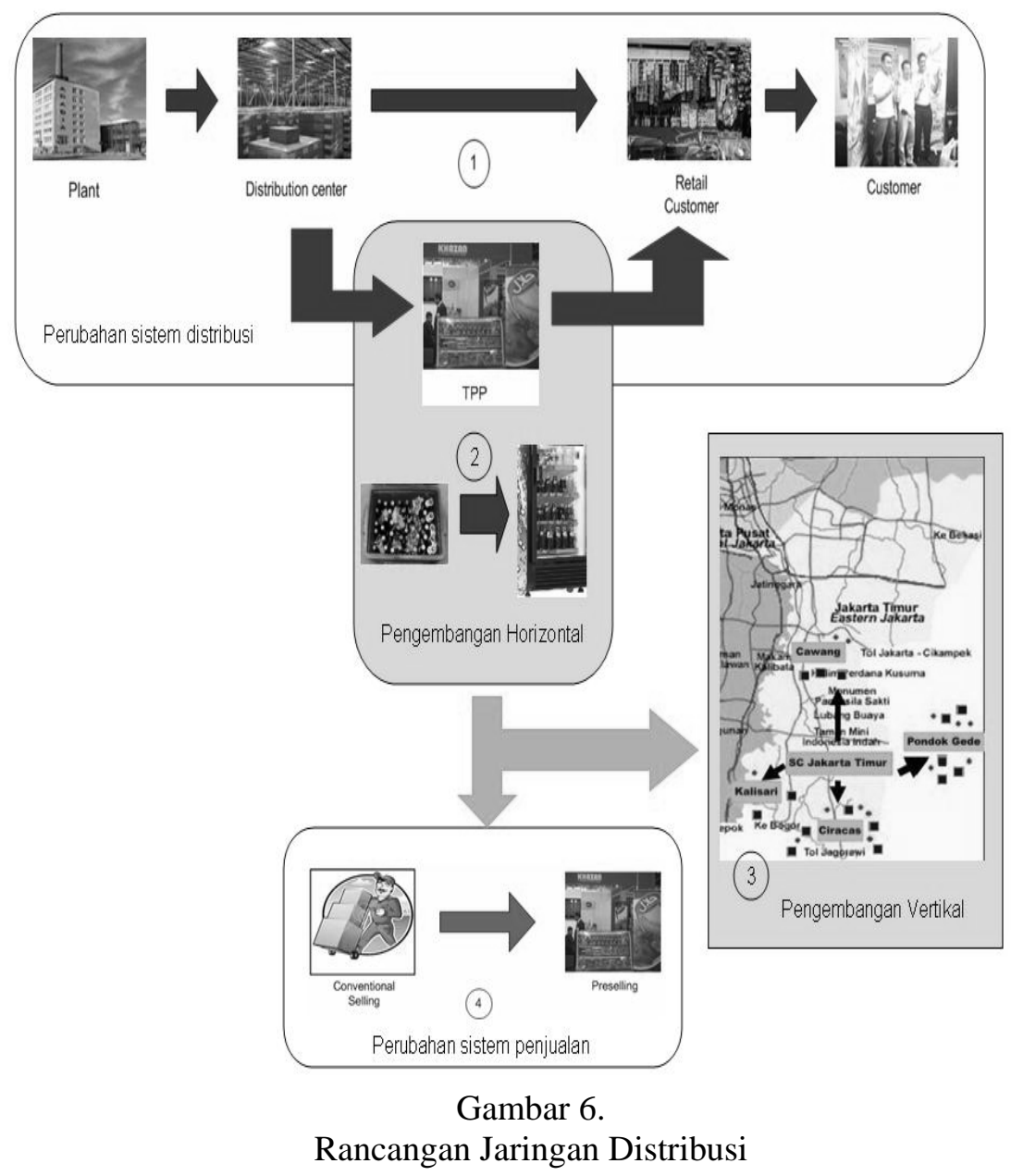

\section{KESIMPULAN DAN SARAN}

Penyusunan rancangan jaringan distribusi dilakukan melalui beberapa proses yakni audit SCM untuk merumuskan strategi supply chain dan mengidentifikasikan prime strategy, audit prioritas wilayah distribusi untuk menetapkan prioritas wilayah distribusi sesuai dengan potensinya dan audit prioritas outlet distribusi untuk menetapkan prioritas jaringan distribusi guna mendukung peningkatan jangkauan (coverage) dan memperkuat market share.

Untuk menjalankan rancangan jaringan distribusi perlu dibuat rencana implementasi yang dibagi menjadi 4 bagian, yaitu penghapusan sistem distribusi langsung, pengembangan sistem distribusi horizontal dan vertikal, serta perubahan 
sistem penjualan dari conventional menjadi Pre-selling.

Adapun untuk mengantisipasi resiko yang muncul perlu dibuat manajemen risiko. Dalam manajemen risiko terdapat 2 kegiatan bersifat kritis yaitu kegiatan menghapus sistem distribusi langsung dan mengubah sistem penjualan dari conventional menjadi pre-selling. Sistem distribusi langsung menjadi kegiatan bersifat kritis karena merupakan dasar pelaksanaan distribusi yang mengatur sistem persediaan dan sistem pengiriman. Demikian pula dengan sistem penjualan, karena merupakan dasar pelaksanaan pemesanan dan pelayanan pesanan. 


\section{DAFTAR PUSTAKA}

Chopra, Sunil and Peter Meindl, Supply Chain Management, Pearson, New Jersey, 2007

Cohen, Shoshanah and Joseph Roussel, Strategic Supply Chain Management, Mc Graw Hill, United States, 2004

Kertajaya, Hermawan, MarkPlus on Strategy, Gramedia, Jakarta 2005

Kodrat, David Sukardi, Old Distribution Channel and Postmo Distribution Channel Approach Berbasis Teori dan Praktik, Graha Ilmu, Yogyakarta. 2009

Kotler, Phillip and Kevin Lane Keller, Marketing Management $13^{\text {th }}$ Edition, Pearson Prentice Hall, New Jersey, 2009

Purnama, Lingga, Strategi Pemasaran, Gramedia, Jakarta 2001

Royan, Frans M, Creating Distribution Strategy, Gramedia, Jakarta, 2005

Saaty, L Thomas, Multicriteria Decision Making: The Analytic Hierarchy Process, Mc Graw Hill, United States, 1990

Schulz, Eric, The Marketing Game, Erlangga, Jakarta, 2001

Simchi-Levi, David, Philip Kaminsky, and Edith Simchi-Levi, Designing and Managing the Supply Chain, Mc Graw Hill, Singapore, 2003

Wheelen, Thomas and David Hunger, Strategic Management and Business Policy, Pearson, New Jersey, 2006

www.cocacolabotlling.co.id

www.anak2industri.blogspot.com.2009 